\title{
YEASTS ASSOCIATED WITH SALTED HERRING AND BRINE, UKRAINE
}

\author{
O.D. Ianieva, K.S. Ogirchuk \\ Zabolotny Institute of Microbiology and Virology, NAS of Ukraine, \\ 154 Akad. Zabolotny Str., Kyiv, 03143, Ukraine \\ e-mail:yandol@ukr.net
}

Yeasts are unicellular eukaryotic microorganisms that are ubiquitously found in various food products especially in foods with low $\mathrm{pH}$, low water activity or high sugar and salt content where most bacteria do not survive. Very little is known about yeast microbiota of processed food popular in Ukraine - salted herring. The aim of this work was to study yeast microbiota composition of salted herring, tolerance of isolated yeasts to various stress factors (salt and sugar stress, food preservatives) and hydrolytic activities that could contribute to the product spoilage. Methods. Yeast strains from salted herring were isolated by serial dilution method and identified according to phenotypic characteristics. Stress tolerance and hydrolytic properties of the isolated strains have been studied. Results. 57 yeast strains were isolated from 10 samples of salted herring and brine obtained from markets and supermarkets in Ukraine. Yeast counts in the samples varied from zero up to $3.69 \log _{10} \mathrm{CFU} / \mathrm{ml}$ or gram of the sample. The isolated yeasts were identified as Debaryomyces hansenii (38\% of isolates), Candida sake (20\% of isolates), Candida zeylanoides (13\% of isolates), Yarrowia lipolytica (9\% of isolates) etc. Most yeasts isolated from salted herring possessed lypolytic activity (98\% of isolates) although only a small proportion of yeasts were strongly proteolytic (7\% of isolates). Most yeasts were non-fermentative (70\% of isolates). Yeasts from salted herring were highly sensitive to such food preservatives as sorbic acid (MIC 0.05-0.25 g/l) and acetic acid (MIC 0.1-1 g/l) at low pH and exhibited the broad range of tolerance to propionate and benzoate. Inhibitory effect of weak organic acids against isolated yeasts decreased manifold at higher $\mathrm{pH}(5.5)$. The high proportion of yeast isolates were highly halotolerant (MIC higher than $150 \mathrm{~g} / \mathrm{l} \mathrm{NaCl}$ ) and could survive osmotic stress (50\% glucose). Conclusions. This work provides characterization of yeast microbiota of salted herring demonstrating its tolerance to salt and osmotic stress and sensitivity to food preservatives.

Keywords: salted herring, yeasts, stress tolerance, hydrolytic properties.

The preservation of food products for long periods of time has been practiced by humans for many thousands of years. Salting is a traditional procedure frequently used to prolong a storage period and avoid spoilage of fish products by inhibiting the development of undesirable bacterial and fungal microbiota [1].

Bacterial microbiota of the processed fish products has been described by various authors. Magnusson et Moller isolated a halophilic Gram-negative bacterium which caused the spoilage of sugar-salted herring by ropiness formation [2]. Both spoiled and non-spoiled samples of marinated herring in Finland showed no yeast presence with high counts of lactic acid bacteria, predominantly Leuconostoc spp. up to $2.4 \times 10^{9} \mathrm{CFU} / \mathrm{g}$ [3]. Edris et al analyzed 125 samples of various fish products in Egypt and found high bacteria counts up to $9.9 \times 10^{5} \mathrm{CFU} / \mathrm{g}$ while yeasts were not detected in some samples (packed 
herring and herring in jars) or found in low numbers up to $9 \times 10^{2} \mathrm{CFU} / \mathrm{g}$ [4]. However not much is known about yeasts presence and species composition in fish products with high salt content especially in countries of Eastern Europe where salted herring is one of the most popular fish products.

The aim of this work was to study yeast microbiota composition of salted herring Clupea harengus, tolerance of isolated yeasts to various stress factors (salt and sugar stress, food preservatives) and hydrolytic activities that could contribute to the product spoilage.

Materials and methods. Yeast enumeration and isolation from salted herring and brine. Five samples of salted herring brine and five samples of salted herring were obtained at the local market (A and F samples) in Bila Tserkva, Ukraine and two supermarkets (B, C, G and $\mathrm{H}$ samples) and two local markets (samples D, E, J and K samples) in Kiev, Ukraine (Table 1). Samples were analyzed the same day on arrival. Fish portions weighing $1 \mathrm{~g}$ were removed with the help of the sterile knife from 3 different places of the fish and homogenized in $9 \mathrm{ml}$ of $0.9 \% \mathrm{NaCl}$ solution. Appropriate decimal dilutions of the samples (salted herring and brine) were made in $0.9 \% \mathrm{NaCl}$ solution and $0.1-1 \mathrm{ml}$ of each dilution was inoculated in triplicate on agar plates containing YPD medium (10 g/l yeast extract, $20 \mathrm{~g} / 1$ peptone, $20 \mathrm{~g} / 1$ glucose, $20 \mathrm{~g} / 1$ agar) and YPD medium containing $6 \% \mathrm{NaCl}$, final $\mathrm{pH} 5.0$, supplemented with $100 \mathrm{mg} / \mathrm{l}$ chloramphenicol and $2.5 \mathrm{~g} / 1$ sodium propionate to inhibit bacterial and fungal growth. The plates were incubated at $25-26^{\circ} \mathrm{C}$ for 1 week. Each morphologically distinct colony was microscopically examined and colonies belonging to yeasts were counted and selected for further research. Each strain was purified by streaking on YPD agar at least 3 times.

Phenotypic identification of isolated yeasts. Isolated yeast strains were characterized based on their morphology, spore and pseudomycelium formation, assimilation of carbon and nitrogen sources, sugar fermentation and other physiological tests performed according to Kurtzman et al [5].

Determination of osmo- and halotolerance of isolated yeasts. Halorolerance of the isolated yeasts were tested in YPD broth containing 10-20\% sodium chloride and in YPD agar medium containing 7-15\% sodium chloride. The ability of yeast strains to grow at high sugar concentrations was tested in YPD broth containing 50-80\% glucose. Suspensions of 48-hour yeast culture grown on YPD agar slants at $25-26^{\circ} \mathrm{C}$ were placed in duplicate on agar plates using a multipoint inoculator. The plates containing $\mathrm{NaCl}$ agar medium were incubated at $25-26^{\circ} \mathrm{C}$ for 2 weeks, while those with glucose agar - for 4 weeks.

The initial yeast concentration in broth media comprised $3-4 \times 10^{4} \mathrm{CFU} / \mathrm{ml}$. The tubes were cultivated at $25-26^{\circ} \mathrm{C}$ for up to a month. Yeast growth at high glucose concentration was determined by serial dilutions on YPD agar plates due to high viscosity of the medium while yeast growth at high $\mathrm{NaCl}$ concentration was measured by optical density at $540 \mathrm{~nm}$.

Determination of weak acids tolerance of isolated yeasts. The ability of yeast strains to grow in medium containing weak acid preservatives was tested on YPD agar medium containing sorbic acid, benzoic acid, propionic acid, acetic acid [6]. Briefly, YPD agar plates containing various concentration of weak acids were inoculated with 48 -hour yeast cultures and incubated at $25-26^{\circ} \mathrm{C}$ 
for 1 week. Minimal inhibitory concentration (MIC) of the studied substance was considered the lowest concentration to completely inhibit yeast growth.

Determination of hydrolytic activity of isolated yeasts. The ability of the isolated yeasts to hydrolyze tributyrin (lipolytic activity), tween-80 (esterase activity), gelatin (proteolytic activity) was determined [6].

Reagents. All the reagents were obtained from NVP "Alfarus", Ukraine.

Results. The microbiological study of 10 samples of salted hering and brine obtained from the local markets and supermarkets revealed that yeasts were recovered in the range of $10^{2}-10^{3} \mathrm{CFU}$ per gram or $\mathrm{ml}$ of sample from most of the obtained samples (Table 1). The highest yeast numbers were observed in brine samples F, H and K, obtained at markets and supermarkets in Bila Tserkva and Kiev - up to $3.69 \log _{10} \mathrm{CFU} / \mathrm{ml}$. One sample of salted herring obtained from Kiev market (sample D) did not produce any yeast colonies.

Table 1

Yeast counts in brine and salted herring samples

\begin{tabular}{|l|c|c|}
\hline Sample & \multicolumn{1}{|c|}{ Source } & $\begin{array}{c}\text { Yeast count }(\log 10 \mathrm{CFU} / \mathrm{g} \\
\text { or ml of the sample) }\end{array}$ \\
\hline A & salted herring, market A in Bila Tserkva & $2,97 \pm 2,18$ \\
\hline B & salted herring, supermarket B in Kiev & $2,07 \pm 1,46$ \\
\hline C & salted herring, supermarket C in Kiev & $2,54 \pm 1,7$ \\
\hline D & salted herring, market D in Kiev & 0 \\
\hline E & salted herring, market E in Kiev & $2,92 \pm 2,02$ \\
\hline F & brine from salted herring, market A in Bila Tserkva & $3,69 \pm 2,52$ \\
\hline G & brine from salted herring, supermarket B in Kiev & $2 \pm 1,24$ \\
\hline H & brine from salted herring, supermarket C in Kiev & $3,55 \pm 2,44$ \\
\hline J & brine from salted herring, market D in Kiev & $1,65 \pm 0,7$ \\
\hline K & brine from salted herring, market E in Kiev & $3,68 \pm 3,04$ \\
\hline
\end{tabular}

* Mean yeast counts ( \pm standard deviation)

57 different yeast strains were isolated from 10 samples of salted herring and brine (Fig. 1). The majority of the yeast strains isolated from herring belonged to Debaryomyces hansenii (39\% of isolates), Candida sake (21\% of isolates), Candida zeylanoides (14\% of isolates) and Yarrowia lipolytica (9\% of isolates). A small proportion of the isolated yeasts belonged to different species of Candida genus. Three strains of red-pigmented yeasts belonging to Rhodotorula spp. and Rhodosporidium were also observed.

A large proportion of the isolated yeasts exhibited a high level of halotolerance both on agar medium and broth media $-40 \%$ of isolates could tolerate more than $15 \% \mathrm{NaCl}$ in YPD broth while for one yeast strain Candida tenuis $5069 \mathrm{MIC}$ of $\mathrm{NaCl}$ was $180 \mathrm{~g} / 1$ (Fig. 2, A). NaCl MICs on agar medium for the isolated yeasts were higher compared to those in the broth medium where $88 \%$ of isolates exhibited growth in the presence of $15 \% \mathrm{NaCl}$. The similar picture was observed during the determination of osmotolerance of the isolated yeasts e.g. the ability to survive at high glucose concentrations (Fig. 2, B). Only one out of 57 isolates could tolerate $60 \%$ glucose in broth medium while $46 \%$ of isolates grew on $60 \%$ glucose agar. Most isolated yeasts 
could grow in 50\% glucose broth with the highest yeast concentration at 1417-th day of cultivation under static conditions with the gradual decrease in yeast numbers after that period (data not shown).
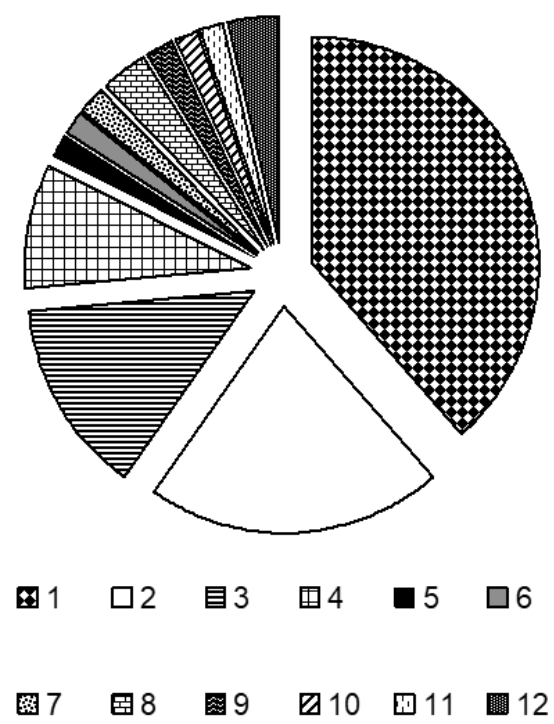

Fig. 1. Yeast microbiota from salted herring identified by phenotypic methods: 1-Debaryomyces hansenii; 2 - Candida sake; 3 - Candida zeylanoides; 4 - Yarrowia lipolytica; 5 - Candida parapsilosis; 6 - Candida tenuis; 7 - Candida carpophila;

8 - Candida sp.; 9 - Rhodotorula sp.; 10 - Rhodotorula mucilaginosa; 11 - Rhodosporidium diobovatum; 12 - not determined

A

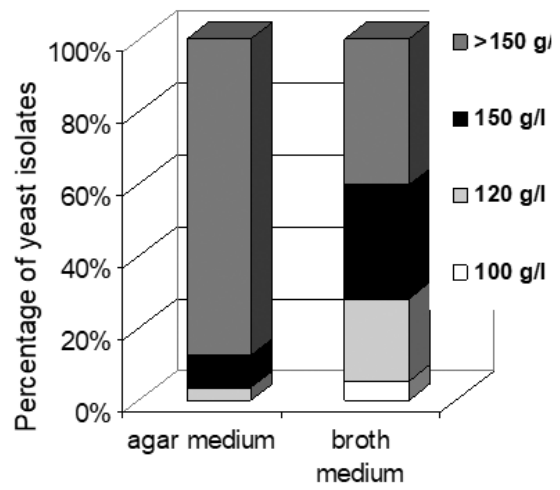

B

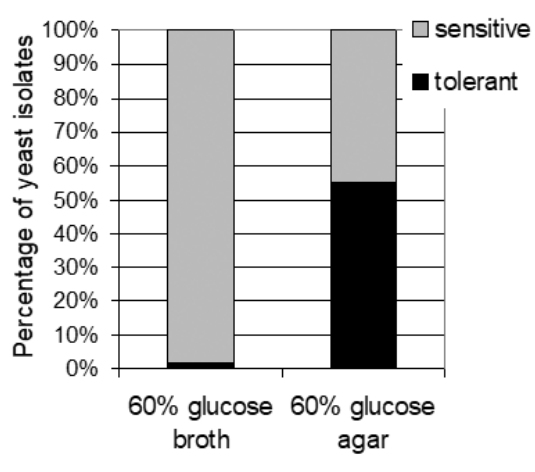

Fig. 2. Salt (A) and sugar (B) tolerance of yeasts isolated from herring

Some stress factors including salt stress are known to affect size and morphology of yeast cells [7]. However the visible effect of high sodium chloride concentration was observed only for one halotolerant strain C. tenuis 5069 which exhibited the highest halotolerance among all the isolated yeasts (MIC of $\mathrm{NaCl}$ in broth - $180 \mathrm{~g} / \mathrm{l}$ ) (Fig. 3). Under salt stress cells grew elongated and produced pseudohyphae while retaining ovoid and bottle-shaped form under salt-free conditions. 
$\mathbf{A}$

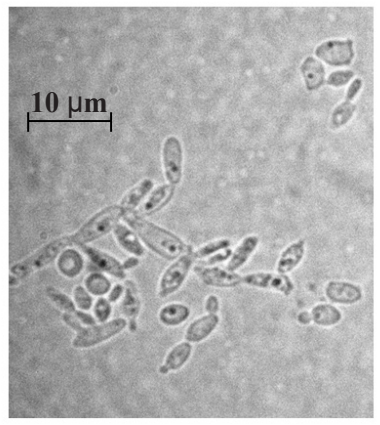

Б

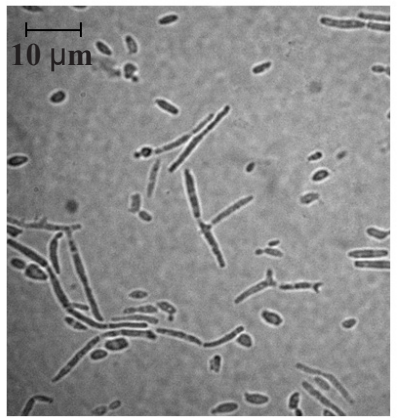

Fig. 3. Cell morphology of halotolerant yeast $C$. tenuis 5069 under salt-free (a) and salt stress (conditions (15\% NaCl broth) (B), 7 days cultivation

The isolated yeasts were tested for their tolerance at $\mathrm{pH} 3.5$ and 5.5 to weak acid preservatives commonly used in food industry for the long-term preservation of food products, e.g. propionic, sorbic, acetic and benzoic acids (Fig. 4). Such compounds exhibit the highest antimicrobial effect at low $\mathrm{pH}$, as the content of undissociated acid which could freely enter yeast cells considerably decreases with $\mathrm{pH}$ increase, e.g. for sorbic acid from $99 \%$ at $\mathrm{pH} 3.5$ to $37 \%$ at $\mathrm{pH} 5.5$ [8].

A

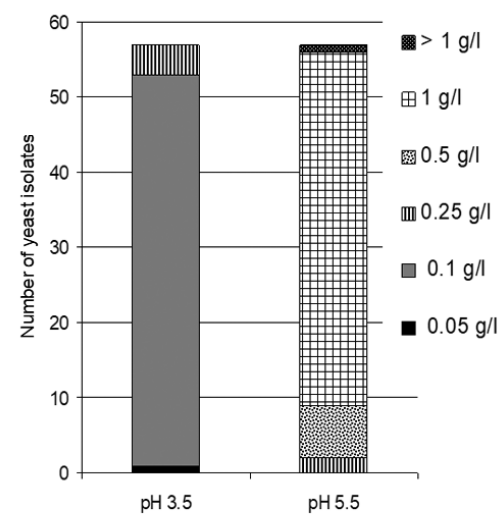

$\mathrm{C}$

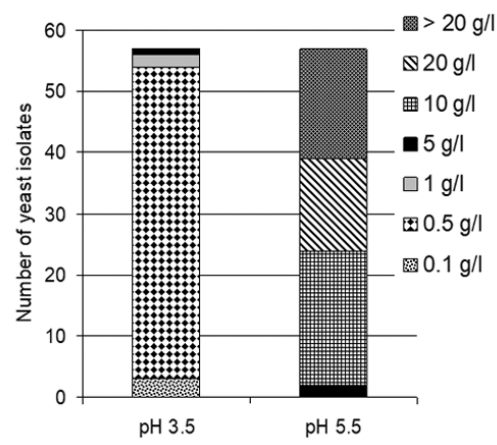

B

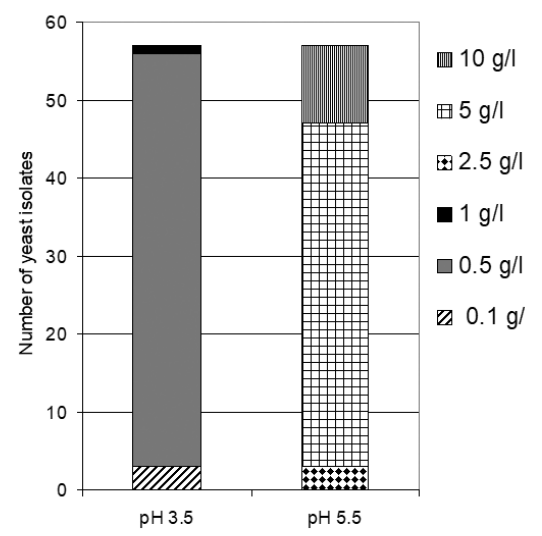

$\mathrm{D}$

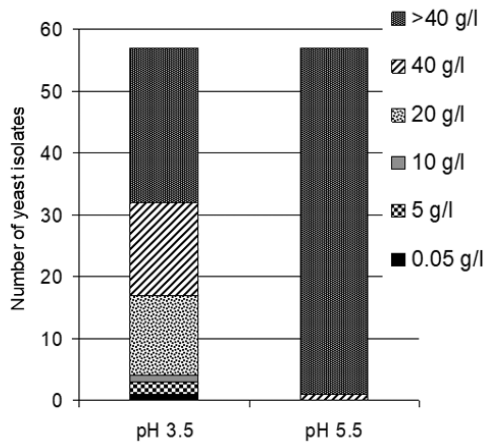

Fig. 4. Tolerance of the isolated yeasts to weak organic acids: sorbic acid (A), acetic acid (B), sodium benzoate (C), sodium propionate (D) presented as minimal inhibitory concentration $(\mathrm{g} / \mathrm{l})$ of the corresponding compound for yeast isolates 
Sorbic acid was the most inhibitory towards the isolated yeasts (Fig. 4, A), its MIC ranging from 0.05 to $0.25 \mathrm{~g} / 1$ at $\mathrm{pH} 3.5$ while increasing 10 -fold for most strains at $\mathrm{pH} 5.5$, the similar trend was observed for acetic acid tolerance MIC of $0.1 \mathrm{~g} / 1$ at $\mathrm{pH} 3.5$ for the vast majority of isolates and $1 \mathrm{~g} / 1$ at $\mathrm{pH} 5.5$ (Fig. 4, B). The isolated yeasts exhibited higher level of tolerance for sodium benzoate and propionate, MIC of benzoate being $0.5 \mathrm{~g} / 1$ for most strains at $\mathrm{pH}$ 3.5 and increasing more than 20 -fold at $\mathrm{pH} 5.5$ while most yeasts could tolerate $10 \mathrm{~g} / 1$ sodium propionate at $\mathrm{pH} 3.5$ and $40 \mathrm{~g} / 1$ at $\mathrm{pH} 5.5$.

The ability of the isolated from herring yeasts to ferment carbohydrates (namely glucose) and hydrolyze such substrates as lipids, ethers and proteins has been determined (Fig.5). Glucose fermentation was observed in $30 \%$ of yeast isolates. All isolates apart from one exhibited lipolytic activity and $11 \%$ of isolates were esterase-positive. Only 4 isolates out of 57 could hydrolyze gelatin.

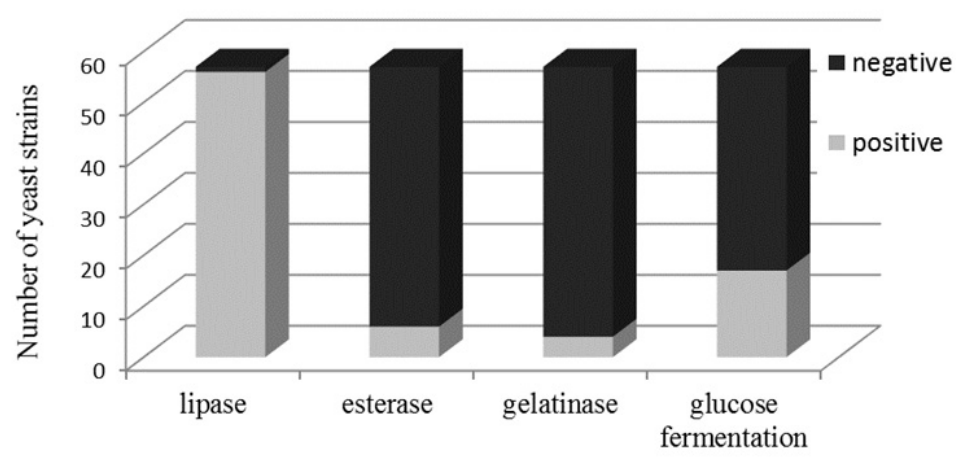

Fig. 5. Hydrolytic and fermenting properties of isolated yeasts

Discussion. The studies show that lactic acid bacteria (LAB) are the frequent cause of microbial contamination of lightly preserved fish products (salt content $4-6 \%$ and presence of weak organic acid preservatives) [3, 9], bacteria belonging to Shewanella and Pseudomonas also greatly contribute to fish spoilage [9]. There are comparatively few mentions of yeast microbiota in saltcured fish products, and such reports greatly vary concerning yeast presence and numbers. According to Leisner there are 3 types of microbial spoilage of salt-cured fish products, one of which could be caused by osmotolerant yeasts growing up to $10^{5} \mathrm{CFU} / \mathrm{g}$ and generating fruity odours while other two are caused by various bacteria [9]. No yeasts were detected in any spoiled samples of marinated herring with high LAB load (up $10^{9} \mathrm{CFU} / \mathrm{g}$ ) [3]. Low numbers of yeasts and molds in the range of $\log _{10} 1.66-1.81$ were detected in dried salted herring samples in the Phillipines [10]. Paskevicius et Varnaite studied the presence of yeasts in fresh and salted herring products and also at fish processing plants, yeast counts in finished herring products comprised $1.3-12 \times 10^{3} \mathrm{CFU} / \mathrm{g}$ or were not detected while raw herring materials contained yeast numbers at least one order of magnitude lower [11]. Jessen demonstrated the growth of spoilage yeasts in brine of marinated herring in numbers exceeding $10^{4} \mathrm{CFU} / \mathrm{g}$ at low temperature and $\mathrm{pH} 5.5$ [12], similar numbers were detected in coldsmoking salmon samples [13]. Thus obtained by us yeast numbers in herring and brine samples are in good agreement with the other studies. We ob- 
served the highest yeast counts in brine samples - up to $3.69 \log _{10} \mathrm{CFU} / \mathrm{ml}$. As Stratford emphasized the yeast counts in various foods up to $10^{4}$ cells $/ \mathrm{g}$ do not apparently affect the quality of the product and food spoilage would be noticeable in the presence of higher numbers of spoilage yeasts $\left(10^{5}-10^{6}\right.$ cells per $\mathrm{ml}$ or gram and higher) [14]. As yeast load did not exceed such numbers in any of the studied herring samples therefore yeast populations in these samples should not negatively affect the quality of salted herring.

The isolated yeasts predominantly belonged to the yeast species wellknown for their prevalence in foods especially in products with low water activity and high salt content. D. hansenii - is one of the most frequent inhabitants of sausages and cured meat, contributing to the taste and flavor due to their enzymatic activities and production of aromatic compounds, in some cases however leading to food spoilage and high economic losses [15]. Yeasts D. hansenii comprising 39\% of yeasts isolated by us from herring are usually characterized by their high tolerance to salt stress being able to survive up to $24 \% \mathrm{NaCl}$ [16]. C. zeylanoides (14\% of the isolates) is also frequently found in various meat products [17]. Paskevicius et Varnaite isolated yeasts belonging to Saccharomyces, Candida, Debaryomyces, Pichia, Yarrowia in fresh and salted herring products and at fish processing plants [11]. Dabrowski et al detected the presence of several yeast genera in low-salt herring samples, Candida, Pichia and red-pigmented yeasts being the dominant ones [18]. Such yeasts as D. hansenii, C. sake, C. parapsilosis, Y. lipolytica are frequently isolated from fish products and various seafoods [19] Thus it could be concluded that yeasts isolated from salted herring samples represent yeast microbiota characteristic for fish and seafood products.

Salt and sugar are some of the earliest known food preservatives. Salt content in herring products could vary from $4-6 \%$ to $18 \%$ depending on the salting process [1] thus leading to the death or inhibition of most microbes and survival of only halotolerant microorganisms. The vast majority of the isolated yeasts $(72 \%)$ could tolerate up to $12 \% \mathrm{NaCl}$ in broth medium while $40 \%$ isolates could tolerate more than $15 \% \mathrm{NaCl}$ in broth. Betts et al studied the effect of various stress factors including sodium chloride on growth of various spoilage yeasts isolated from foods most of which could grow at $\mathrm{NaCl}$ concentrations up to $8 \%$ [20]. Out of 65 yeast strains isolated from high sugar foods 8 yeasts were able to grow at $20 \% \mathrm{NaCl}$ concentration while $81 \%$ of strains tolerated $10 \% \mathrm{NaCl}$ [21]. Thus we could presume that food products with low water activity (high salt and/or sugar content) may serve as an excellent reservoir for halotolerant yeasts.

Weak organic acids (sorbic, acetic, etc.) are compounds with well-established antimicrobial activity used in food industry to inhibit the growth of undesirable microorganisms, benzoic, sorbic and acetic acids being permitted for fish preservation [22]. Yeasts isolated by us from herring samples were characterized by high sensitivity to sorbic and acetic acid (MIC of sorbic acid $0.1 \mathrm{~g} / 1$ at $\mathrm{pH} 3.5$ and $1 \mathrm{~g} / 1$ at $\mathrm{pH} 5.5$ for most isolates, MIC of acetic acid $0.5 \mathrm{~g} / 1$ at $\mathrm{pH} 3.5$ and $5 \mathrm{~g} / 1$ at $\mathrm{pH} 5.5$ for most isolates). The tolerance of the isolated strains to sorbic acid was similar to that of Pichia guilliermondii and 
Candida halophila strains isolated from spoiled products with high sugar content by Martorell et al. [23] while MIC of acetic acid for yeasts isolated by us was several times lower. At pH 4 MIC of sorbic acid for Saccharomyces cerevisiae was 0,34-0.39 g/l while for the spoilage yeast Zygosaccharamyces bailii - 2-3-folds higher [24].

Most isolated yeasts were inhibited by $0.5 \mathrm{~g} / 1$ sodium benzoate at $\mathrm{pH} 3.5$ while at $\mathrm{pH} 5.5 \mathrm{MIC}$ of this compound increased 20 -folds and higher. The similar pattern was detected for yeast strains by Shimazaki et al. who observed a 10-fold increase in MIC of sodium benzoate for Saccharomyces cerevisiae from $0.8 \mathrm{~g} / \mathrm{l}$ at $\mathrm{pH} 4$ to $8 \mathrm{~g} / \mathrm{l}$ at $\mathrm{pH} 5$ and 15 -fold increase in MIC at $\mathrm{pH} 6-$ to $12 \mathrm{~g} / 1$ [25]. Propionate is known for its antimold activity at the same time being much less effective against yeasts and bacteria [8]. A wide range of tolerance to propionic acid and its salts are reported for yeasts isolated from various foods - ranging from lack of inhibitory effect of propionate in spoilage yeasts isolated from milk [26] to growth inhibition of several spoilage yeast strains by comparatively low concentrations of propionate of less than $10 \mathrm{~g} / \mathrm{l}$ at $\mathrm{pH}$ 4.5 [27]. $93 \%$ of yeasts isolated from herring tolerated $10 \mathrm{~g} / 1$ propionate at $\mathrm{pH} 3.5$ while the permitted level of this preservative in various foods in EU is $3-5 \mathrm{~g} / \mathrm{kg}[28]$.

In general, yeasts isolated from salted herring samples did not exhibit high levels of tolerance to weak acid preservatives being especially sensitive to sorbic and acetic acids.

Mendoza et al studied enzymatic profiles of yeasts isolated from sausages fermented in $2.5 \%$ brine where vast majority of yeasts were lipopytic and many esterase-positive although few possessed proteolytic activity [29]. Proteolytic activity was detected in $18 \%$ of yeasts isolated from raw and processed herring products while $41 \%$ of isolates were lipolytic [30]. Kobatake et al isolated 103 psychrotrophic yeast strains from raw seafoods many of which possessed proteolytic activity and causing fish spoilage [31]. It is a well-established fact that fish products, herring in particular, contain high levels of protein and fat [32], therefore lipolytic and proteolytic microorganisms with high tolerance to salt stress could cause salted fish spoilage. Only a small proportion of isolated by us yeasts (7\%) possessed proteolytic (gelatinase) activity while most were lipolytic, $10.7 \%$ of isolates were esterase-positive. So, it could be presumed that yeasts isolated from salted herring and brine samples could potentially cause herring spoilage by fat hydrolysis though less so by proteolysis of the product.

Conclusion. Little is known about yeast microbiota of salted fish products. 57 yeast strains belonging to $D$. hansenii, C. sake, C. zeylanoides, Y. lipolytica were isolated from 10 samples of salted herring and brine. The reported results show that yeasts isolated from herring represented yeast species ubiquitous in foods with high salt content, were tolerant to salt and osmotic stress while being sensitive to weak acid preservatives, especially at low $\mathrm{pH}$. The majority of isolated yeasts were lipolytic while a small proportion exhibited esterase and gelatinase activities. 


\title{
ДРІЖДЖІ, АСОЦІЙОВАНІ 3 СОЛОНИМ \\ ОСЕЛЕДЦЕМ В УКРАЇНІ
}

\author{
О.Д. Янєва, К.С. Огірчук
}

Інститут мікробіології і вірусології імені Д.К. Заболотного НАН Украӥни, вул. Академіка Заболотного, 154, Київ, 03143, Україна

\section{Резюме}

Дріжджі - одноклітинні еукаріотичні мікроорганізми, які широко розповсюджені в різноманітних харчових продуктах, особливо з низькими показниками $\mathrm{pH}$, активності води або високим вмістом цукру або солі, де більшість бактерій не здатні вижити. Майже нічого не відомо про дріжджову мікробіоту в такому популярному в Україні продукті, як солоному оселедці. Метою цієї роботи було дослідити склад дріжджової мікробіоти в зразках солоного оселедця, стійкість ізольованих дріжджів до різних стресових факторів (сольового та осмотичного стресу, харчових консервантів) та їх гідролітичні властивості, що можуть призвести до псування продукту. Методи. Культури дріжджів із зразків оселедця були ізольовані методом серійних розведень та ідентифіковані відповідно до фенотипових ознак. Було визначено стійкість ізольованих дріжджів до стресових факторів та їх гідролітичні властивості.

Результати. 57 штамів дріжджів було ізольовано з 10 зразків солоного оселедця та розсолу, придбаних на ринках та супермаркетах в Україні. Кількість дріжджів в зразках варіювала від нуля до $3.69 \log _{10}$ КУО/мл. Ізольовані дріжджі були ідентифіковані як Debaryomyces hansenii (38\% штамів), Candida sake (20\% штамів), Candida zeylanoides (13\% штамів), Yarrowia lipolytica (9\% штамів) та ін. Більшість ізольованих дріжджів мали ліполітичну активність (98\% штамів), але лише невеликий відсоток 3 них були протеолітичними (7\% штамів). Більшість ізолятів не були здатні до ферментації глюкози (70\% штамів). Виділені дріжджі характеризувалися високою чутливістю до таких харчових консервантів, як сорбінова (МІК 0.05-0.25 г/л) та оцтова кислоти (МІК 0.1-1 г/л) за низького значення $\mathrm{pH}$ та демонстрували широкий спектр стійкості до бензоату та пропіонату. Пригнічуюча дія слабких органічних кислот щодо ізольованих дріжджів знижувалася в рази при підвишенні $\mathrm{pH}$ середовища до 5.5. Значна частина дріжджів характеризувалася високим рівнем галотолерантності (МІК $\mathrm{NaCl}$ вище 150 г/л) та осмотолерантності (здататності до росту при 50\% глюкози). Висновки. В роботі представлені дані щодо видового складу дріжджів, ізольованих із солоного оселедця, їх стійкість до сольового та осмотичного стресу та чутливість до харчових консервантів.

Ключові слова: оселедець, дріжджі, толерантність до стресу, гідролітичні властивості. 


\title{
ДРОЖЖИ, АССОЦИИРОВАННЫЕ С СОЛЕНОЙ СЕЛЬДЬЮ В УКРАИНЕ
}

\author{
О.Д. Янева, Е.С. Огирчук
}

Институт микробиологии и вирусологии НАН Украинь, ул. Академика Заболотного, 154, Киев, 03143, Украина

\section{Резюме}

Дрожжи - это одноклеточные эукариотические микроорганизмы, широко распространенные в разных пищевых продуктах, особенно с низкими показателями $\mathrm{pH}$, активности воды или высоким содержанием соли или сахара, где большинство бактерий не выживает. Мало известно о дрожжевой микробиоте в таком популярном в Украине продукте, как соленая сельдь. Целью данной работы было определить состав дрожжевой микробиоты в образцах соленой сельди, устойчивость изолированных штаммов к различным стрессовым факторам (солевой и осмотический шок, пищевые консерванты) и их гидролитические свойства, которые могут вести к порче продукта. Методы. Штаммы дрожжей были выделены из образцов сельди методом серийных разведений и идентифицированы согласно фенотипическим признакам. Были определены устойчивость выделенных дрожжей к стрессовым факторам и их гидролитические свойства. Результаты. 57 штаммов дрожжей было выделено из 10 образцов соленой сельди и рассола, приобретенных на рынках и супермаркетах в Украине. Количество дрожжей в образцах варьировало от нуля до $3.69 \log _{10}$ КОЕ/мл. Выделенные дрожжи были отнесены к таким видам: Debaryomyces hansenii (38\% штаммов), Candida sake (20\% штаммов), Candida zeylanoides (13\% штаммов), Yarrowia lipolytica (9\% штаммов) и др. Большинство изолятов обладали липолитической активностью (98\% штаммов), небольшой процент штаммов характеризовался протеолитическими свойствами (7\% штаммов). Большинство выделенных дрожжей были неферментирующими (70\% штаммов). Выделенные дрожжи характризовались высокой чувствительностью к таким пищевым консервантам, как сорбиновая (МИК 0.05-0.25 г/л) и уксусная кислоты (МИК 0.1-1 г/л) при низком значении $\mathrm{pH}$ и широким спектром устойчивости к бензоату и пропионату. Антимикробное действие слабых органических кислот снижалось в разы при повышении рН среды до 5.5. Значительная часть изолятов характеризовалась высокой галотолерантностью (МИК $\mathrm{NaCl}$ выше 150 г/л) и осмотолерантностью (способности к росту при 50\% глюкозы). Выводы. В работе представлена характеристика дрожжей, выделенных из образцов соленой сельди, их устойчивость к солевому и осмотическому стрессу и чувствительность к пищевым консервантам.

Ключевые слова: сельдь, дрожжи, устойчивость к стрессовым факторам, гидролитические свойства.

1. Voskresensky N.A. Salting of herring. Fish as food, 3 Vol. (ed G. Borgstrom). New York, London: Academic Press, 1965:107-13.

2. Magnusson H., Moller A. Ropiness in the brine of sugar-salted herring. Int J Food Microbiol. 1985; 1(5):253-261.

3. Lyhs U., Koort J.M., Lundström H.S., Björkroth K.J. Leuconostoc gelidum and Leuconostoc gasicomitatum strains dominated the lactic acid bacterium population associated with strong slime formation in an acetic-acid herring preserve. Int J Food Microbiol. 2004; 90(2):207-18. 
4. Edris A.B.M., Hasanen F.S., Khater D.F., Lela R.A. Microbiological studies on some fishery products. Benha Vet Med J. 2012; 23(1):185-191.

5. Kurtzman CP, Fell JW, Boekhout T, Robert V. Methods for isolation, phenotypic characterization and maintenance of yeasts. The Yeasts, a Taxonomic Study, 5th ed. Elsevier, 2011:87-110.

6. Ianieva O.D. Tolerance of yeasts isolated from pickled cucumbers to stress factors. Microbiol Z. 2017; 79 (5): 34-45.

7. Andreishcheva E.N., Isakova E.P., Sidorov N.N., Abramova N.B., Ushakova N.A., Shaposhnikov G.L., Soares M.I.M., Zvyagilskaya R.A. [Adaptation to salt stress in a salt-tolerant strain of the yeast Yarrowia lipolytica]. Biochemistry (Moscow). 1999; 64 (9): 1061-67. Russion.

8. Deak T. Handbook of food spoilage yeasts. Boca Raton, USA: CRC Press, 2007. 352 p.

9. Leisner J.J., Gram L. Spoilage of fish. Encyclopedia of Food Microbiology, R. Robinson, C. A. Batt, \& P. Patels (Eds.) San Diego: Academic Press, 2000: 813-820.

10. Gabriel A.A., Alano-Budiao A.S. Microbial, physicochemical, and sensory quality evaluations of salted herring (Sardinella fimbriata) subjected to different drying processes. Food Sci Technol Res. 2015; 21 (2): 213-221.

11. Paskevicius, A. Varnaite, $R$. Yeast occurrence in herring products and processing environment and their biochemical peculiarities. Pol J Food Nutr Sci. 2010; 60 (4): 369-373.

12. Gram L. Microbiological Spoilage of Fish and Seafood Products. Compendium of the Microbiological Spoilage of Foods and Beverages (ed. W.H. Sperber, M.P. Doyle). Springer: New York, USA, 2009: 87-119.

13. Leroi F., Joffraud J.J., Chevalier F., Cardinal M. Study of the microbial ecology of cold-smoked salmon during storage at 8 degrees C. Int J Food Microbiol. 1998; 39 (1-2): 111-121.

14. Stratford M. Food and beverage spoilage yeasts. Yeasts in food and beverages. Berlin, Germany: Springer, 2006:335-79.

15. Breuer U., Harms H. Debaryomyces hansenii - an extremophilic yeast with biotechnological potential. Yeast. 2006; 23 (6): 415-437.

16. Javor B. Yeasts and fungi. Hypersaline environments: microbiology and biogeochemistry. Berlin ; New York : Springer-Verlag; 1989. p.163-175.

17. Purrinos L., Fontan M.C.G., Carballo J., Lorenzo J.M. Study of the counts, species and characteristics of the yeast population during the manufacture of dry-cured "lacón". Effect of salt level. Food Microbiol. 2013; 34 (1): 12-18.

18. Dąbrowski W., Różycka-Kasztelan K., Czeszejko K., Mędrala D. Microflora of lawsalt herring. The influence of sodium benzoate on microflora of low-salt herring. Electr. J Po. Agric Univ. 2002; 5(2): \#14.

19. Deak T. Handbook of food spoilage yeasts. Boca Raton, USA: CRC Press; 2007. $352 \mathrm{p}$.

20. Betts G.D., Linton P., Betteridge R.J. Food spoilage yeasts: effects of pH, $\mathrm{NaCl}$ and temperature on growth. Food control. 1999; 10 (1): 27-33.

21. Senses-Ergul S., Karasu-Yalcin S., Ozbas Z.Y. The effect of some environmental parameters on the growth of yeasts originating from sugar containing foods. Annals Microbiol. 2007; 57 (2): 191-196. 
22. ICMSF. Microorganisms in Foods 6: Microbial Ecology of Food Commodities, $2^{\text {nd }}$ edition. New York: Kluwer Academic/Plenum Publishers; 2005. 763p.

23. Martorell P., Stratford M., Steels H., Fernández-Espinar M.T., Querol A. Physiological characterization of spoilage strains of Zygosaccharomyces bailii and Zygosaccharomyces rouxii isolated from high sugar environments. Int J Food Microbiol. 2007; 114(2): 234-42.

24. Stratford M., Steels H., Nebe-von-Caron G., Novodvorska M., Hayer K., Archer DB. Extreme resistance to weak-acid preservatives in the spoilage yeast Zygosaccharomyces bailii. Int J Food Microbiol. 2013; 166(1):126-34.

25. Shimazaki A, Sakamoto JJ, Furuta M., Tsuchido T. Antifungal activity of diglycerin ester of fatty acids against yeasts and its comparison with those of sucrose monopalmitate and sodium benzoate. Biocontrol Sci. 2016; 21(2):123-30.

26. Xu XL, Feng GL, Liu HW, Li XF, Zhao GL, Xiao XL. Isolation, identification and control of osmophilic spoilage yeasts in sweetened condensed milk. Afr J Microbiol Res. 2014; 8(10): 1032-9.

27. Moon NJ. Inhibition of the growth of acid tolerant yeasts by acetate, lactate and propionate and their synergistic mixtures. Appl Microbiol. 1983; 55(3):453-460.

28. EFSA Panel on Food Additives and Nutrient Sources added to Food. Safety of the extension of use of sodium propionate (E 281) as a food additive. EFSA Journal. 2016; 14 (8) e04546.

29. Mendoza L.M., Padilla B., Belloch C., Vignolo G. Diversity and enzymatic profile of yeasts isolated from traditional llama meat sausages from north-western Andean region of Argentina. Food Res Inter. 2014; 62: 572-579.

30. Brizzio S, Turchetti B, de García V, Libkind D, Buzzini P, van Broock M. Extracellular enzymatic activities of basidiomycetous yeasts isolated from glacial and subglacial waters of northwest Patagonia (Argentina). Can J Microbiol. 2007; 53(4):519-25.

31. Kobatake M, Rij Kreger-Van N.J.W., Placido M.T.L.C., Uden N.V. Isolation of proteolytic psychrotrophic yeasts from fresh raw seafoods. Lett Appl Microbiol. 1992; 14 (2): $37-42$.

32. Usydus Z., Szlinder-Richert J., Polak-Juszczak L., Komar K., Adamczyk M., MalesaCiecwierz M., Ruczynska W. Fish products available in Polish market--assessment of the nutritive value and human exposure to dioxins and other contaminants. Chemosphere. 2009; 74 (11): 1420-28.

Отримано 29.11.2017 